\title{
CARAVANAS DE HOMBRES MARCHABAN: EL ÉXODO OBRERO EN ENTRE RÍOS. 1925-1945
}

\author{
Caravanas de hombres marchaban: \\ The Worker Exodus in Entre ríos. 1925-1945
}

Rodolfo Leyes*

\section{Resumen}

La migración de mano de obra es uno de los hechos más dramáticos y permanentes del capitalismo. La República Argentina formó su proletariado a partir de contingentes transatlánticos y de las regiones vecinas menos desarrolladas. Sin embargo, desde la década de 1920, las migraciones cambiaron. Las provincias pampeanas, receptoras de población hasta ese momento, comienzan a expulsar mano de obra sobrante. Un proceso que tiene por trasfondo la mecanización de tareas rurales que impone el éxodo como horizonte de vida a miles de trabajadores.

La llegada de estos obreros a las grandes urbes del litoral -Buenos Aires particularmente- ha dado lugar a una discusión historiográfica al respecto de la base social de quienes apoyaron a Perón aquel histórico 17 de octubre de 1945. En este contexto, aportamos con el presente trabajo al conocimiento de los motivos de la migración, el proceso histórico en marcha, el papel del Estado y los programas políticos en discusión sobre la migración, visto todo, desde una provincia expulsora: Entre Ríos. Para una construcción más fehacientes nos hemos basado en periódicos de diversas corrientes ideológicas, documentación estatal, material estadístico y memorias de exiliados, así como un repaso por las obras bibliográficas fundamentales.

$<$ Migrantes internos $><$ Crisis $><$ Sobrepoblación obrera $><$ Peronismo $>$

\begin{abstract}
Workforce migration is one of the most dramatic and permanent facts of capitalism. From transatlantic contingents and less developed neighbouring regions, Argentina shaped a proletariat. However, migrations changed since the 20's. The provinces of the Pampa region, up to this time population receivers, began to expel surplus labour. This process' background lays on farm tasks mechanization and imposes exodus to thousands of workers.

The arrival of workers to major cities of the littoral -particularly, Buenos Aires- gave room to a historiographical discussion about the social basis of those who supports Perón on that historical October 17th, 1945. Within this context, this work contributes to the knowledge of migration causes, the historical process in progress, the role of the state and political programs in dispute about migration, all of this, seen from an expelling province: Entre Ríos. For a more reliable development, I analyze different sources such as newspapers of diverse ideological line, state documentation, statistic materials, and memoirs of expelled people, as well as main bibliography review.
\end{abstract}

$<$ Internal migration $><$ Crisis $><$ Worker overpopulation $><$ Peronism $>$

Recibido: 16/11/2016 // Aceptado: 30/11/2016

* Licenciado en Historia. CONICET/Facultad de Humanidades, Artes y Ciencias SocialesUniversidad Autónoma de Entre Ríos. rodolfoleyes@yahoo.com.ar 


\section{ARTÍ́CULOS}

Leyes. Caravanas de hombres marchaban: el éxodo obrero en Entre Ríos. 1925-1945.

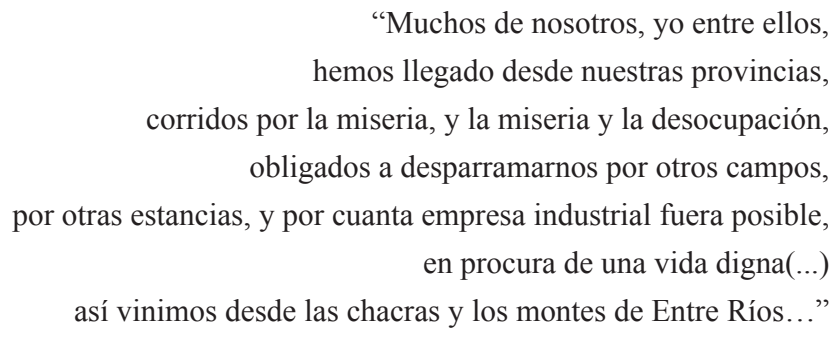

(Peter, 1968:10)

José Peter, dirigente comunista del sindicato de la carne.

\section{Introducción}

Dentro de las transformaciones que el capitalismo genera, el éxodo de la mano de obra es una de sus marcas de época. Argentina no escapa a movimientos demográficos, primero como receptora en el ambiente rural, luego en la conformación de grandes urbes. En el caso de Entre Ríos, se ubican aquellos contingentes trasatlánticos y de otras regiones del litoral en diferentes poblados, dando vida a la campaña en las denominadas "colonias agrarias", lugar donde se desarrolló la producción agrocerealera, complementaria a la producción ganadera.

Llegada la década de 1920, comenzó un movimiento inverso, desterrando población rural. Signada por las transformaciones tecnológicas, el reemplazo de mano de obra por nuevas máquinas ofrecía como destino a los trabajadores o desocupación o éxodo. La provincia de Entre Ríos aportó miles de trabajadores que se convirtieron en migrantes internos, especialmente habitantes de las grandes urbes de las provincias de Buenos Aires y Santa Fe.

El hecho de que sean entrerrianos - como santafesinos, pampeanos o cordobeseslos primeros migrantes masivos, puede aportar luz a los estudios sobre la relación entre los migrantes internos y el surgimiento del peronismo. Aportar a dicho debate con la perspectiva de la provincia expulsora. Sin embargo, diremos que no se trata de "una vez más" sobre el origen del peronismo - parafraseando a Juan Carlos Torre- sino, de participar del estudio del fenómeno migratorio. Reconocer qué clases o fracciones fueron las más afectadas por el proceso de expulsión, reconstruir históricamente como fue dicho proceso, los motivos, las zonas de expulsión, su tamaño y una posible periodización.

La reconstrucción histórica se hizo en base a una variedad de fuentes que incluyen periódicos de diversas ciudades y tendencias ideológicas, material estatal, compuesto por informes, producción estadística y documentación oficial variada.

\section{En el centro del debate: migrantes internos, clase obrera y peronismo}

El migrante interno surge a la historiografía como objeto explicativo y de disputa en la explicación del surgimiento del peronismo. La problemática, luego de aquellos enfrentamientos originarios, fue prácticamente abandonada por los estudiosos, frente 
a una nueva ortodoxia -como astutamente la llamó Torcuato Di Tella- (Di Tella, 2003: 11).Como prueba de sus dichos, en una conferencia reciente, Daniel James afirmó que la respuesta de Halperín Donghi a Germani (James, 2013: 140-141; Halperín Donghi, 1980: 219-250.), había cerrado los análisis sobre los migrantes internos, dando un giro en la historiografía sobre el peronismo. Así, las posiciones contrarias a Germani se han convertido en nuevas máximas, a pesar de existir preguntas por hacerse. Sin embargo, cada tiempo en tanto, la discusión sobre los migrantes internos vuelve a su sentido original, a su vinculación con la histórica elección de febrero de 1946 para ser refutada, al decir de Nicolás Quiroga (Quiroga, 2016: 179).

El texto inaugural de la historiografía sobre el peronismo fue el ya clásico de Gino Germani, Política y sociedad en una época de transición, de 1962. En aquella obra, el autor, intentó dar una explicación sobre el proceso histórico que atravesó la sociedad argentina. Se dispuso al análisis del fenómeno peronista, que solo siete años antes había sido derrocado del poder estatal y claramente había conmovido la base social de la Argentina ${ }^{1}$. Germani señaló que entre los años 1936-1947, se había dado un proceso de migración interna "elevadísima" -respetando la palabra utilizada por el autor- y que este flujo migratorio de grandes masas trasplantadas de manera rápida del campo a la ciudad, compuesto por jornaleros especialmente, no encontró en el nuevo ambiente urbano canales institucionales para su absorción dentro del sistema democrático-burgués. Ni siquiera por parte de los partidos obreros, que no supieron proporcionar una expresión adecuada a las demandas de los recién llegados, poseedores de valores primitivos en materia de participación institucional, acostumbrados al caudillismo. El golpe de 1943 abrió, según él, las puertas a un tipo nuevo de gobierno totalitario específicamente americano, que serían los gobiernos "nacional-populares", y se habría convertido en vehículo de aquellas demandas no reconocidas, a su vez, los migrantes internos, serían masas disponibles, útiles a los planes de los uniformados. Patrones psico-sociales comunes hicieron que aquellas masas disponibles reconozcan en el Coronel Perón la fuerza carismática de los viejos caudillos con los que estaban emparentados en sus lugares de origen. Esa relación es la que explicaría los éxitos del peronismo (Germani, 1962: 230-252).

Una explicación de ese tipo no tardó en ser criticada. La publicación en 1969 de "El movimiento obrero en los orígenes del peronismo", segunda parte del trabajo más conocido como: Estudio sobre los orígenes del peronismo, de Miguel Murmis y Juan Carlos Portantiero fue la piedra fundamental de lo que se llamó "Tesis revisionista" (Murmis y Portantiero, 2006). El centro de su ataque era la supuesta división entre una "vieja" y una "nueva" clase obrera la cual consideraban amalgamada o con una experiencia acumulada por algunas décadas de vida en las grandes ciudades. El trabajo de los críticos pone el acento en la continuidad de muchos viejos sindicatos y dirigentes en la conformación del sindicalismo peronista. Mostrando así que no eran los nuevos sindicatos industriales -supuestamente compuesto por los migrantes recientes- los

${ }^{1}$ Germani aclara que el grueso de la reflexión sobre el peronismo fue escrita en 1956 y de allí continuó reflexionando sobre dicho fenómeno (Germani, 1962: 233). 


\section{ARTÍ́CULOS}

Leyes. Caravanas de hombres marchaban: el éxodo obrero en Entre Ríos. 1925-1945.

primeros en recibir a Perón, sino que habían sido muchos de los antiguos sindicatos (Murmis y Portantiero, 2006: 113-186). Conclusión final: no hay una relación diferencial en el apoyo a Perón, entre los "viejos obreros" y "nuevos obreros".

Germani no se mantuvo incólume a las críticas. Publicó uno de sus últimos trabajos: "El surgimiento del peronismo: El rol de los obreros y de los migrantes internos" (Germani, 1980: 87-163.)², donde reafirmó sus dichos y cuestionó las críticas. Señaló que el peso de obreros urbanos era mayor que el otorgado por sus críticos, por otro lado acusó una operacionalización errónea de los datos. También se refirió a la proporción de los migrantes internos y retomó el cuerpo de su tesis original sobre las formas asociativas.

Es probable que la muerte en 1979 de Gino Germani haya sido el motivo de la interrupción del debate, más que los argumentos de Halperín Donghi. Sin embargo, no podemos dejar pasar por alto algunos elementos importantes que Halperín señaló, a saber: los inmigrantes extranjeros son diversos en su comportamiento, recorrido social, forma de sociabilidad y adaptación a la Argentina de la primera mitad del siglo XX, por lo cual, no se puede establecer un tipo ideal. Algo análogo sucedió con los migrantes internos. No solo que no eran del origen que Germani señaló, sino que las características de estos eran más complejas de lo que se creía. Otra de las críticas de Halperín apuntó a las bases materiales que empujaron a la migración, sobre las que nos referiremos en el próximo apartado, asimismo, y tal vez lo más importante, registraba el origen provincial de los primeros migrantes, no en la periferia de la pampa húmeda, sino en su corazón. (Halperín Donghi, 1980).

Hacia fines de la década del 90, el trabajo de Roberto Korzeniewicz, (Korzeniewicz, 1993) no hizo más que profundizar las líneas revisionistas, en especial, sobre el carácter de continuidad entre el movimiento obrero anterior al 17 de octubre y el posterior. La referencia al debate sobre la nueva y la vieja clase obrera era un paso inevitable pero enmarcado dentro del estado del problema y como algo saldado. La "nueva ortodoxia" se impuso, no sin razón.

En los últimos años, el debate ha vuelto a ser retomado. Nos referiremos a tres trabajos o avances de trabajo de destacados investigadores que reanudan el estudio del objeto con perspectivas disimiles. Por antigüedad de la publicación nos ocupamos primero del trabajo de Omar Acha (Acha, 2008). El trabajo cuestiona y demuestra cómo fue la conformación de las familias a través de las actas de matrimonio que muestran el origen de los cónyuges y su ocupación. Con esto mostró el peso de las mujeres en

${ }^{2}$ En una publicación póstuma, escrita en 1973, Germani matizaba la participación casi exclusiva de los "nuevos obreros" afirmando que: “...para las clases populares de formación urbana y moderna y con experiencia sindical, se trataba de una adhesión condicionada por las circunstancias, el único camino viable para expresar las necesidades de la clase obra en las condiciones dominantes en esa época.", ver: Germani, 1992: 80- 83.

${ }^{3}$ El trabajo de Korzeniewicz complementa las críticas de Halperín Donghi. Desarrolla tres puntos fundamentales y contrarios a Germani: A) El tamaño de la migración, en particular los errores de cálculos por parte de Germani. B) La composición de origen de los migrantes, continuando la línea de Halperín sobre el origen de los migrantes y, C) El papel político de los migrantes internos, en particular su peso. 
determinadas colectividades provinciales y algunas de las pautas de sociabilidad. En el caso de las mujeres entrerrianas que migraron, obreras en su mayoría, eligieron en sus matrimonios compañeros que le permitan mejorar su condición social (Acha, 2008: 424). Su obra, cumple en este sentido con las palabras de Quiroga, nuevas perspectivas para seguir el estudio de un objeto que continúa abriendo preguntas. En este sentido, el reciente artículo de Amaral (Amaral, 2015) desarrolla en buena medida un trabajo de difusión y metodológico sobre la pregunta clásica de los migrantes internos: ¿A quién votaron en febrero de 1946? Apoyado en el trabajo de Cantón y otros (Cantón, Acosta \& Jorrat, 2013) El trabajo parte del entrecruzamiento de los inscriptos a las elecciones y el crecimiento vegetativo. Así muestra qué departamentos o partidos (el articulo está centrado en la provincia de Buenos Aires) fueron los que perdieron población y cuales tuvieron un saldo favorable. La crítica que se le puede hacer a este método es que deja afuera las mujeres migrantes y a los inmigrantes transatlánticos no nacionalizados. Es decir, quedan afuera los migrantes no-votantes. Sin embargo, los resultados generales a los que llega son coherentes con otras investigaciones demográficas. (Amaral, 2015: 87. Cfr.: Recchini de Lattes y Lattes, 1969).

Dentro de estas nuevas perspectivas se enmarca el artículo de Quiroga que hicimos alusión en esta actualización de las investigaciones (Quiroga, 2016). En él, Quiroga realiza una propuesta de investigación que aún resta ser realizada o bien publicada para un público más amplio, ya que aparecen enunciadas como hipótesis justificada. Las preguntas giran en torno al estudio de la separación simbólica entre el interior y Buenos Aires y por otro lado, la división de color, es decir, como reaccionó la sociedad que se creyó blanca a la llegada de "cabecitas negras" (Quiroga, 2016, 190). Ambas preguntas necesitan de un abordaje amplio que trascienda la ciencia histórica. El riesgo es el trato ecléctico que busca en ciencias auxiliares y expresiones literarias retazos que apoyan la línea de problematización expuesta.

Para finalizar el repaso de los trabajos y aportes, no se puede omitir el único trabajo disponible sobre las migraciones internas específicamente de Entre Ríos. Me refiero al trabajo de Marcos Henchóz, docente de la Universidad Autónoma de Entre Ríos, quién publicó "La migración interna en el sudeste entrerriano hacia 1940" (Henchóz, 2013). Lamentablemente, la obra no ofrece explicaciones por fuera del sentido común que reduce la crisis y la migración a un problema del reparto de la tierra, razón que tiene origen en el uso de bibliografía desactualizada. Parece equivocar la estructura agraria entrerriana con la santafecina, ofrece datos que no tienen origen documentado y en los casos que lo hace se destaca el uso de las Síntesis estadísticas de la provincia de Entre Ríos, que poseen proyecciones estimativas y no relevamientos anuales de la población. ${ }^{4}$

${ }^{4}$ La provincia de Entre Ríos, realizaba anualmente una serie de estadísticas que eran un verdadero balance de la provincia. Sin embargo, en materia de la evolución demográfica, se limitaba a una estimación matemática. Para tener una idea del "margen" de error, podemos presentar la proyección para 1945, que era de 892.208 entrerrianos, divididos entre 330.643 que habitarían las ciudades y 561.565 en el campo. Un año más tarde, cuando se realizó el Cuarto Censo nacional, los resultados relevados en el terreno eran otros: la provincia de Entre Ríos poseía una población de 787.362 habitantes (104.846 personas menos que las estimaciones provinciales). De los cuales 421.314 eran habitantes urbanos y los restantes 


\section{ARTÍ́CULOS}

Leyes. Caravanas de hombres marchaban: el éxodo obrero en Entre Ríos. 1925-1945.

En la utilización de las cifras de aquellas fuentes se hace un uso, por lo menos, descuidado. El autor utiliza el crecimiento vegetativo del campo y el de la ciudad, compara este con el crecimiento de la ciudad cabecera, para concluir que el saldo negativo se debe a migrantes hacia Buenos Aires. Aunque no explica cómo sabe que se fueron hacia esa provincia. Es pertinente anticipar que dentro del mismo espacio provincial también hubo migraciones y que tampoco la migración fue un proceso exclusivo del campo, sino que afectó también a los pueblos y ciudades. Por otro lado, y siguiendo a Germani acríticamente, equivoca la época en que comenzó la migración y considera que la expulsión se dio entre 1938 y 1947, aunque páginas más adelante indique que "hacia 1946 comenzó a darse el proceso de migración interna hacia las ciudades cabeceras de la zona y hacia las grandes ciudades industrializadas..." (Henchóz, 2013: 35, 36, 40 y 41). La obra de Henchóz no ofrece explicaciones, aunque vale reconocer que la existencia de un trabajo específico puede indicar un problema a ser tratado desde la óptica del lugar de expulsión.

Sin intenciones de agotar el inmenso universo de estudios sobre el peronismo, podemos afirmar que en lo fundamental los debates más serios sobre el surgimiento de este movimiento giran en torno a la figura del "migrante interno", como uno de sus ejes de polémica. La mayoría de los trabajos justifican el estudio de los migrantes de cara al debate con el surgimiento del peronismo, sin embargo, resta conocer y estudiar el proceso de expulsión. Fundamentalmente, los porqués de la migración. En este sentido, recogemos el guante arrojado por Daniel James. Nuestro trabajo trata de mostrar la razón estructural, el tamaño de la expulsión y realizar aportes en el conocimiento histórico del proceso durante el periodo elegido desde la provincia expulsora y no la receptora como normalmente se ha tratado.

\section{Los motivos de la migración: Una perspectiva estructural}

Más arriba nos referimos al universo por estudiar con respecto a los migrantes internos. Sin lugar a dudas, el o los motivos por los cuales se produjo la desocupación deberían ocupar un lugar central en el estudio, ya que, la relación entre desocupación y éxodo es fundamental. Por nuestra parte, creemos poder aportar pruebas de que la desocupación por mecanización fue el proceso que generó falta de trabajo de modo persistente en los años del estudio, más allá de los efectos que las situaciones coyunturales como la crisis comercial de los años 1930-1935, las sequías periódicas, las lluvias, inclusive, plagas como las langostas.

Para reconocer este proceso es necesario un acercamiento al corazón del capitalismo entrerriano, es decir, a su producción rural. Halperín Donghi, en los debates

366.048 en el ambiente rural. Es decir, inversamente a la ubicación otorgada por la proyección del Estado provincial. Como se ve, las estimaciones estaban equivocadas como para ser consideradas fidedignas en la reconstrucción histórica. Cfr.: Entre Ríos. Ministerio de Hacienda, Dirección General de Estadística, Síntesis Estadística: Año 1944-1945, Paraná, Imprenta de la Provincia, 1946, p.9. República Argentina. Ministerio de Asuntos técnicos del Estado, Dir. Gen. Del Serv. Est. Nacional, IV Censo General de la Nación: Censo Agropecuario de 1947, Buenos Aires, Dirección Nacional del Servicio Estadístico, 1947. Tomo I, p. LXIX. 
citados recordaba a Germani que la mayoría de los migrantes internos eran de la región pampeana que, como él mismo había reconocido, estaba en pleno proceso de transformación. (Halperín Donghi, 1980: 227). El historiador mencionó tres cambios que deben ser considerados: el cambio de producción cerealera (trigo y maíz) a una de tipo industrial (lino) que significó un menor uso de mano de obra asalariada. El aumento de la superficie productiva, y no la disminución como señaló Germani. Por último, que estas transformaciones se producen en la pampa húmeda, lo que explica el origen de la masa poblacional expulsada ¿Qué proceso puede tener semejante conmoción en el aparato productivo? ¿Qué podía generar un crecimiento sostenido de la agricultura y expulsar población a la vez?

Desde mediados de la década de 1920, ayudados por los buenos precios internacionales de los cereales, la burguesía agrícola se dio a la tarea de renovar su parque tecnológico y agregar a sus planteles productivos nuevas maquinarias para mejorar la producción. Este cambio en la composición del capital invertido, que priorizó los desembolsos de capital constante (fundamentalmente maquinarias, aunque se incluye la tierra y otros bienes) por encima del capital variable (salarios) generó un cambio en la ocupación de mano de obra y la estructura social (Sartelli, 1995).

Estas transformaciones se materializan en el desarrollo productivo. En la provincia de Entre Ríos, desde 1927 hasta 1937 la superficie productiva se mantuvo en crecimiento. Una serie de factores coyunturales, dados por una sequía persistente hizo que se reduzca la superficie productiva en casi un 35\%, pasando de 1.531 .110 hectáreas a 1.004.013 hectáreas entre 1935 y 1943. En tanto, la transformación en el tipo de plantíos se puede rastrear hacia 1929, cuando el trigo era más del $40 \%$ de la producción con 515.219 hectáreas $^{5}$.

La producción entrerriana guarda - como es lógico- una similitud al resto de la pampa húmeda. Sería extenso revelar el proceso completo de las ramas y actividades más significativas afectadas por la mecanización. Tarea que, por cierto, ya hemos hecho en otro trabajo, ${ }^{6}$ aunque tomaremos algunos ejemplos de las transformaciones a las que nos referimos.

Uno de los casos paradigmáticos fue el creciente reemplazo de las grandes trilladoras por las cosechadoras-trilladoras. Hacia 1914 existían 936 de las primeras contra 43 cosechadoras-trilladoras. En 1937, las trilladoras alcanzaban las 1.174 contra 2.453 cosechadoras-trilladoras. Una década más tarde, las unidades existentes eran 595 trilladoras contra 3.367 cosechadoras $^{7}$. Además del aumento de las maquinarias contadas

${ }^{5}$ Entre Ríos. Ministerio de Gobierno. Dirección General de Estadística, Síntesis Estadística: Año 1929, Paraná, Imprenta Oficial, 1930, S/N. Ministerio de Agricultura. Censo General agropecuario de 1937. resultados generales (Cifras Provisionales), Buenos Aires, S/E, 1938, p.37-38. Entre Ríos. Ministerio de Hacienda, Dirección General de Estadística, Síntesis Estadística: Año 1943, Paraná, Imprenta de la Provincia, 1944.

${ }^{6}$ Hemos desarrollado in-extenso esta posición para Entre Ríos, en una ponencia presentada y en la cual aún estamos trabajando, se puede consultar: Leyes, 2013.

${ }^{7}$ República Argentina. Tercer Censo Nacional, Tomo V, Explotaciones Agropecuarias, Buenos Aires, Talleres Gráficos L. J. Rosso y Cía, 1919, p. 585. Ministerio de Agricultura. Censo nacional agropecuario: 1937, 


\section{ARTÍ́CULOS}

Leyes. Caravanas de hombres marchaban: el éxodo obrero en Entre Ríos. 1925-1945.

por unidades, lo más importante eran sus características productivas. Mientras una de las viejas trilladoras ocupaba entre 22 a 25 trabajadores, una cosechadora-trilladora lo hacía con solo 5 a 6 trabajadores. Por otra parte, realizaba la tarea más rápido, unificando la cosecha con la trilla y no, como dos momentos separados del proceso productivo como hasta entonces (Sartelli, 1997). A esto, deberíamos agregar que la mano de obra puede ser abastecida por miembros de la propia familia del chacarero, lo cual reduce aún más la demanda de obreros. Esto era percibido por los periódicos contemporáneos que se expresaban de esta manera:

"Desocupación en la campaña: En estos momentos en toda la campaña de la provincia se siente una casi absoluta falta de trabajo, que es motivo de preocupación general. La adaptación de nuevas máquinas a la recolección de las cosechas, ha hecho que las tareas rurales que antes llegaban hasta abril, estén una casi por completo terminadas, con lo que quedan sin ocupación numerosos obreros. Algunos diarios de la provincia prestan atención al asunto considerando con razón, que se plantea con la desocupación un problema cuyo estudio se impone con urgencia, a fin de buscar los medios de solucionarlo." (El Entre Ríos, Colón, 21/02/1929).

Otras dos maquinarias que hicieron retroceder la demanda de trabajadores fueron el tractor y la llegada del camión. Uno y otro ayudaron especialmente a la reducción del tiempo de preparación de la tierra y del transporte, respectivamente. Además, en el caso del camión, su utilización sirvió a modificar la naturaleza del transporte, reemplazó las características bolsas de arpillera -con su dificultad estacional de abasto, poca durabilidad y alto costo- y permitió el transporte a granel que facilitó el uso del elevador de granos, lo que disminuyó el trabajo de estiba en los grandes puertos y estaciones de trenes. Como lo señalaba el periódico sindicalista El Despertar, de Concepción del Uruguay:

"Sabido es que en el interior de nuestra Provincia la vida económica depende del movimiento que trae en sí el movimiento de las cosechas, en primer lugar lo que tiene de valor para la misma vida del comercio local, que depende en gran parte del movimiento de jornales que reciben los trabajadores galponeros por su trabajo en los galpones, y el movimiento de bolsas hace más activo el comercio, da más vida localmente, pues con buenas cosechas pueden trabajar hasta cuatro o cinco meses. El elevador viene a restringir estas entradas en un $70 \%$ en cada localidad, ya que donde antes se empleaban

Buenos Aires, Guillermo Kraft Ltda., 1940, p.189. República Argentina. Ministerio de Asuntos técnicos del Estado, Dir. Gen. Del Serv. Est. Nacional, IV Censo General de la Nación: Censo Industrial de 1947, Tomo III, Buenos Aires, Dirección Nacional del Servicio Estadístico, 1952, pp. 486-491. 
para los trabajos de movimientos del cereal 15 hombres no bien llega la máquina, se tornan a penas 3 o 4 hombres y estos solo deben pensar en trabajar apenas dos meses cuando mucho (...) Esto trae como consecuencia inevitable la considerable disminución de medios de adquisición que además de colocar a los trabajadores al borde de la mayor miseria trae también como reflejo de esto la decadencia del propio comercio, que va muriendo lentamente, y se hallan en la necesidad de emigrar buscando nuevos horizontes, esto no es una simple profecía, ya que en todas las estaciones que hasta ayer fueron progresistas y donde se notaba intensa actividad, hoy se puede ver la mayor miseria y tanto los trabajadores como el comercio deben de huir corriendo por estos males". (El Despertar, C. del Uruguay, Enero de 1936).

Por si fuera poco, la industria ovina, una de las principales tareas estacionales, que llegó a ocupar más de 40 mil jornaleros durante la esquila, redujo su stock de animales debido al cambio del lugar de producción -el desplazamiento hacia el sur argentino- (Giberti, 1986: 195) cuando se pasó de casi 7 millones de cabezas a poco más de dos millones y medio de animales ${ }^{8}$. Y fundamentalmente, la adquisición de máquinas esquiladoras, que a reemplazaron las viejas tijeras por un sistema mecánico que aumentó la productividad de los trabajadores ocupados 9 .

Hay que agregar que los proletarios con tierra y los chacareros empobrecidos que no hayan podido hacer las inversiones en tecnología, vieron su frágil economía conmoverse en su composición interna, al limitarse la posibilidad de ser ocupados por otros chacareros más productivos. Asimismo, el abandono del campo no se trastocó en su reciclaje en la industria urbana local, que atravesada el mismo proceso. En la industria, los últimos años de la década del 20 también fueron de fuerte inversión en maquinarias (Villanueva, 1972: 458). En 1917, la provincia de Entre Ríos poseía 2.382 establecimientos manufactureros e industriales, con una capacidad instalada medida en 12.672 HP que ocupaba 18.004 obreros. En 1946, la cantidad de establecimientos era de 2.324, los obreros ocupados, 18.256; mientras tanto, los HP, fuerza motriz de las máquinas, se había elevado a $93.587^{10}$. En casi tres décadas, la cantidad de establecimientos apenas había disminuido, los obreros ocupados se mantenían relativamente estancados, mientras

\footnotetext{
${ }^{8}$ República Argentina. Censo Agropecuario Nacional, la ganadería y la agricultura en 1908: La Ganadería, Buenos Aires, Talleres de Publicaciones de la Oficina Meteorológica, 1909, Vol. I., pp.57, 283, 378. Entre Ríos. Ministerio de Hacienda, Dirección General de Estadística, Síntesis Estadística: Año 1944-1945, Paraná, Imprenta de la Provincia, 1946, p. 57.

${ }^{9}$ Barcón Olesa, J. El estado de Entre Ríos. Álbum gráfico y exposición sintética de sus elementos de progreso, Paraná, S/E. 1912, p.30. República Oriental del Uruguay. Comisión de Ganadería, Ramos Montero, A. La esquila con máquina: resultados que ha producido en el país, Montevideo, Talleres Barreiro, 1910, pp.15-24, 39.

${ }^{10}$ Ministerio de Agricultura. Estadística comercial e industrial de la Provincia de Entre Ríos, Boletín № 26 , 1917, pp. 33 y 40. IV Censo General de la Nación: Censo Industrial de 1947, Tomo III, p. 74.
} 


\section{ARTÍ́CULOS}

Leyes. Caravanas de hombres marchaban: el éxodo obrero en Entre Ríos. 1925-1945.

la fuerza motriz se había septuplicado. Solo para ilustrar estas transformaciones en el aparato productivo y de los procesos de trabajo, veremos el caso que tenemos mejor estudiado que es la fábrica Liebig, de Colón.

Las fábricas de conservas eran las industrias más grandes de la provincia. Para 1914 se ocupaban en tres establecimientos 4.227 obreros. En 1935, en lo más crudo de la crisis, los tres establecimientos que ocuparon 757 obreros. La recuperación de la postguerra no aumentó la ocupación, los cuatro establecimientos existentes en 1946, ocuparon 356 empleados administrativos y 2.957 obreros $^{11}$. El establecimiento Liebig era la mayor manufactura de extracto de carne de la provincia de Entre Ríos. En 1924 llegó a ocupar más de 3.500 trabajadores $^{12}$. Desde aquel año, las condiciones objetivas de la producción en la Fábrica Liebig comenzaron a cambiar. Se instaló una noria, que regulaba el movimiento de los vacunos enganchados, así se logró imponer mayores ritmos a los operarios y eliminar tiempos muertos. La instalación constaba de una noria principal por la que corría la media res. Luego, se repartía hacia otras dos norias: una por dónde circulaban colgadas las cabezas y otra por donde lo hacían las vísceras. También se utilizó a partir de aquellos años una máquina que quitaba el cuero al animal antes de ser cortado en dos, manejada por un solo obrero. En 1927, uno de los medios de prensa local informó con el título "Se necesitan obreros":

"Nos informó un dirigente de la Compañía Liebig's, que dicho establecimiento se está trabajando intensamente, faenando de 1400 a 1500 novillos diarios, y que posiblemente se dará trabajo a varios millares de obreros, durante todo el año, pues se introducirán en el vasto establecimiento grandes innovaciones, entre ellas estarán las poderosas turbinas que se encuentran en viaje y que fueron adquiridas en Inglaterra, como también la construcción de un grandioso edificio de dos o tres pisos para la instalación de las maquinarias modernas y otras dependencias que serán instaladas en él. Esta noticia ha de ser bien recibida por nuestro comercio y sobre todo por los numerosos obreros que desean trabajar y que tenemos entendido son muchos, por lo menos, los que se la pasan sin trabajar." (Diario Del Pueblo, Colón, 05/07/1927)

A pesar de la lectura promisoria del medio informativo, otro periódico, dos años más tardes, se hizo eco de los cambios y sus consecuencias:

"Obreros sin trabajo: Debido a que en Fábrica Colón se emplea este año un número menor de trabajadores que en las

\footnotetext{
${ }^{11}$ Ministerio de Agricultura. Estadística comercial e industrial de la Provincia de Entre Ríos, Boletín № 26, 1917, p. 131. Ministerio de Hacienda. Comisión Nacional del Censo Industrial, Censo Industrial de 1935, Buenos Aires, DGEN- Casa Jacobo Peuser, 1938, p.244. IV Censo General de la Nación: Censo Industrial de 1947, Tomo III, p. 106.

${ }^{12}$ Argentine Republic. 1925. The province of Entre Rios, Economical Political and Geographical synthesis, S/L, S/E., pp.11-12.
} 
faenas de los anteriores, existe en nuestra ciudad un crecido número de obreros desocupados, que en su mayor parte son personas de otras partes que han venido al iniciarse las tareas del establecimiento, creyendo encontrar fácilmente trabajo, como ha ocurrido hasta el año anterior. La reducción de obreros en las tareas de Liebig se debe a que las maquinarias del establecimiento han sido aumentadas con otras modernas, que hacen mayor trabajo con menos personal. Por esta causa actualmente no se trabaja de noche, como en los años anteriores." (El Entre Ríos, Colón, 24/01/1929)

Las transformaciones no se detuvieron aquí. Se remplazaron ollas donde se cocinaba la carne. Anteriormente se empleaban diferentes ollas a la que se traspasaba la producción manualmente. El nuevo sistema de encadenamiento de ollas, unidas por rampas espiraladas hacía todo automáticamente. Finalmente, el relleno de las latas con el producto que, hasta aquel momento se ejecutaba en forma semi-automática por una decena de mujeres que utilizaban cucharas con la medida de la lata, y colocaban la tapa metálica que era sellada por una máquina, fueron reemplazadas por una máquina "entarradora" de origen francés, y la utilización de una cinta transportadora de latas. La otra sección transformada y en la que se ocupaban especialmente mujeres, era la "latería", donde el pintado manual de las latas con barniz fue reemplazado por una máquina que hacía la misma tarea más rápido y con menos personal (Barreto, 2003: 131-132; Rodríguez, 1988: 39). Es tal vez a ésta máquina a la que hacía alusión El Entre Ríos de junio de 1941:

"Se nos había dado, anoche, una información desasosegante para nuestros círculos proletarios. Según ella, la Compañía Liebig's habría despedido a centenares de obreros, haciéndose ascender ese número a una cifra alarmante. Nos informamos, hoy, que solamente habían quedado 400 obreros sin trabajo, y se nos explicó que la disminución producida obedecía al hecho de haberse puesto en funcionamiento las máquinas para el envasado de 6 libras, las cuales exigen un menor número de operarios (...) Sería sensible que, en los actuales momentos, se confirmaran otras versiones graves sobre las labores de esa Compañía, de cuya veracidad no es posible informarse pero a las cuales no conviene aún darles importancia" (El Entre Ríos, Colón, 24/06/1941).

De esta transformación de las fuerzas productivas es que se desprenden las dos clases sociales que debieron migrar. Los obreros, en especial los menos calificados, y los chacareros y semi-proletarios con tierras. Como se explicará más adelante. 


\section{ARTÍ́CULOS}

Leyes. Caravanas de hombres marchaban: el éxodo obrero en Entre Ríos. 1925-1945.

\section{El tamaño del éxodo}

La movilización de fuerza de trabajo es, como ya se dijo, una de las marcas de época del capitalismo. En una mirada más global, sabemos que el capitalismo ha expulsado y atraído población al ritmo de la expropiación y destrucción de las formas de vida previas a su surgimiento. Este ha sido el origen primario de las grandes migraciones -las mayores en la historia de la humanidad hasta el presente- que se produjeron a mediados del siglo XIX, con el desplazamiento de las poblaciones empobrecidas de Europa (Hobsbawm, 2005). En tanto los mercados se transforman, las poblaciones se moverán a su ritmo, ya sea por la conformación de mejores espacios de venta de fuerza de trabajo o la posibilidad del ascenso social.

La provincia de Entre Ríos, desde los tempranos tiempos de la gran expansión decimonónica, fue receptora de la mano de obra transatlántica y de las provincias vecinas -Corrientes, Buenos Aires y el Estado Oriental- ${ }^{13}$. Más tarde fue proveedora de obreros a otras provincias. Así lo recordaba Bialet Massé en su Informe sobre el estado de la clase obrera argentina de 1905, donde relata la ocupación de obreros entrerrianos estacionales en la cosecha de trigo y maíz en Santa Fe (Bialet Massé, 1985: 153). Durante el periodo intercensal 1895-1914, la cantidad de entrerrianos fuera de la provincia era de unas 25 mil personas: 10 mil en Santa Fe y otros 15 mil en Buenos Aires (Recchini de Lattes y Lattes, 1969: 128-129). Con esto queremos señalar que las migraciones eran un hecho social con el cual el capitalismo se desarrolló sin ser por ello, una situación traumática. La migración de la mano de obra era estacional y significaba un abasto de fuerza de trabajo que luego -en la mayoría de los casos- volvía a sus lugares de origen a ocuparse en sus tareas o mantenerse desocupados hasta el próximo ciclo de cosecha o faena (Sartelli, 1993: III).

El proceso de emigración, diferente a la migración estacional, comenzó en la década del centenario y se profundizó en la de 1920. Resulta difícil señalar en qué año, aunque, si se tiene en cuenta lo dicho más arriba sobre el origen de la expulsión de mano de obra, podemos señalar que fue en algún momento del segundo quinquenio de aquella década. Sin embargo los medios periodísticos recién se hacen eco llegada la década del treinta. Decía el presidente de la Comisión encargada de relevar el Tercer Censo nacional, Alberto Martínez en 1914:

“...concentrándome a investigar cuáles son en la República, las provincias que se pueden clasificar de emigración, es decir, aquellas que ven alejarse de su territorio un número de hijos mayor que el de los de otras provincias que van a radicarse en la misma; y de emigración aquellas en que se produce un fenómeno demográfico contrario, compruebo que las provincias de primera categoría son Entre Ríos, Corrientes, San Luis, Santiago del Estero, San Juan, La Rioja, Catamarca y Salta, y en los territorios Neuquén..."(República Argentina,

\footnotetext{
${ }^{13}$ República Argentina, Primer Censo de la República Argentina, verificado en los días 15, 16 y 17 de 1869 , Buenos Aires, Imprenta El Porvenir, 1872, pp. 152-153.
} 
1916: 239).

Después de argumentar sobre la falta de empleo y la carencia de industria, indica la suma de 47.072 entrerrianos que habitaban fuera de la provincia, lo que contrasta con la cifra propuesta por los Lattes, que se referían unos 25 mil para el mismo periodo. Vale agregar que el valor ofrecido por el censo, equivale al 12,3\% de la población. Otra dato, para indicar el peso de la emigración es que, en el cómputo de ingresos y egresos, nos da un saldo negativo de 30.269 personas. Es decir, la población que migraba hacía Entre Ríos, no compensaba a los emigrados, lo que se llama una migración neta negativa ${ }^{14}$ (Recchini de Lattes y Lattes, 1969: 128-129).

Para el siguiente censo nacional, el de 1947, nos debemos apoyar en los cálculos de Lattes y Rechinni de Lattes, que indican una migración de 125 personas. Expulsando 21 mil personas a la provincia de Santa Fe, 50 mil a la provincia de Buenos Aires -sin especificar si se trata de su conurbano o el interior- y otros 50 mil a la Capital Federal (Recchini de Lattes y Lattes, 1969: 128-129).Si comparamos porcentajes, los datos demográficos pueden ser más duros. El censo de 1947 indicó una población de 787.363 personas en Entre Ríos, por lo cual, los 125 mil entrerrianos afuera equivalen al 16\% de sus habitantes ${ }^{15}$.

Hay que agregar que los censos - delos cuales se valieron los Lattes para su informe- tienen el error de indicar sólo a los nacidos en la provincia y censados fuera de ella. Por lo cual, todos los inmigrantes ultramarinos que hubieran emigrado de Entre Ríos, ${ }^{16}$ habrán quedado fuera del cálculo de la población expulsada de aquella provincia ${ }^{17}$. En una provincia como Entre Ríos, con grandes contingentes de migrantes transatlánticos, es más que probable que haya pobladores que vivieron un tiempo en ella para luego volver emigrar. ${ }^{18}$

\section{Los caminos}

Es difícil aseverar las rutas seguidas por quienes migraron. La documentación disponible indica que los obreros fueron en su mayoría los que abandonaron la provincia,

\footnotetext{
${ }^{14}$ República Argentina. Tercer Censo Nacional, Tomo I, Antecedentes y comentarios, Buenos Aires, Talleres Gráficos L. J. Rosso y Cía. 1916, p. 240.

${ }^{15}$ Una cifra menor, la ofrece Pio Isaac Monteagudo, trabajando con datos del Cuarto censo nacional, aunque sin referenciar páginas. En su caso señala que la población entrerriana para aquel censo era de 787.362 habitantes -número oficial vertido por aquel censo- mientras fuera de la provincia habitaban 76.648 entrerrianos, basado en el total de entrerrianos censados en el país. Ver: Monteagudo, 1956: 55.

${ }^{16}$ Eran el 17,04\% de la población en Entre Ríos de 1914 y el 5,29\% para 1947.

${ }^{17}$ República Argentina. Tercer Censo Nacional, Tomo I, Antecedentes y comentarios, Buenos Aires, Talleres Gráficos L. J. Rosso y Cía. 1916, p.202. IV Censo General de la Nación: Censo Industrial de 1947, Tomo III p. LXIII.

${ }^{18}$ El caso del socialista Enrique Dickmann, nacido en Lituania,vivió en ER y luego migró a BA, es un caso conocido de estos. Pero la colectividad judía, a la que Dickmann pertenecía en un sentido laxo, puede ser un ejemplo paradigmático de poblaciones que volvieron a migrar luego del viaje transatlántico. Ver: Dickmann, 1949: 17-51.
} 


\section{ARTÍ́CULOS}

Leyes. Caravanas de hombres marchaban: el éxodo obrero en Entre Ríos. 1925-1945.

mientras los chacareros se dirigieron a las ciudades cabeceras, ${ }^{19}$ haciendo que la relación entre campo y la ciudad se haya revertido. Según el censo de 1947, por primera vez en la historia provincial, la población urbana superó a la rural. En 1927 se proyectó 238.781 $(38,3 \%)$ personas viviendo en las ciudades y 383.068 en el ambiente rural. Veinte años después, el cuarto censo nacional informó que, 434.029 entrerrianos vivían en la ciudad (56\%) contra los 342.251 que aún permanecían en el campo ${ }^{20}$.

También es dificultoso indicar cuáles fueron los departamentos que más población expulsaron. Para poder realizar el cálculo sería necesario sumar los nacimientos, la inmigración y la población establecida para luego descontar las defunciones, así tendríamos el cálculo de cuantos se han ido. Otro método, más sencillo, para el cual tampoco tenemos la información suficiente, sería revisar los orígenes de las poblaciones de otras provincias o naciones y descontar a los nacidos en la provincia de estudio (Martínez y Gómez García, 2002). Este método, es deficitario en dos sentidos, en primera instancia porque sería una tarea titánica conocer a través de las partidas de nacimiento a los que se movilizaron internamente o dentro de la misma provincia. El segundo problema que brota de éste método es el de las poblaciones que no han nacido en la provincia, que han vivido un tiempo en ella y luego han vuelto a migrar, como el caso ya indicado de los inmigrantes transatlánticos.

Es por esto que la respuesta no se puede dar de modo cerrada o se haga de modo incompleto, recurriendo a otras fuentes, menos fieles pero disponibles, como son los periódicos. Sin embargo, el siguiente cuadro realizado con censos nacionales compara los valores demográficos y la evolución por departamento en sus poblaciones urbanas y rurales.

Del cuadro se desprende un crecimiento poblacional en el orden del $85 \%$ con respecto al censo anterior. Sin embargo, lo más rico, surge de un acercamiento por departamento y la comparación urbano/rural. Creemos que se pueden notar los dos movimientos demográficos aquí descritos: el éxodo del campo a la ciudad y el abandono de la provincia. Ambos procesos, que se verán, no fueron territorialmente homogéneos.

Como se puede apreciar, hacia 1946, por primera vez en la historia de la provincia, la población urbana es mayor que la rural ${ }^{21}$. Tendencia que se irá en aumento

\footnotetext{
${ }^{19}$ Sin dudas esta hipótesis se merece un estudio en sí mismo, pero es viable que dado que el proceso de expropiación no se concreta en un cien por cien de una vez, es posible que el abandono de la chacra se deba a su inviabilidad en términos productivos, sin que signifique su perdida, aunque deje de ser su principal medio de vida. De allí que luego, la ganadería no se haya visto tan afectada, o que el arriendo se haya convertido en fuente de apropiación de renta. La realidad del agro-pampeano se puede consultar en: Barsky \& Gelman, 2005: Cap. VIII. Y Sartelli, 2008.

${ }^{20}$ Entre Ríos, Ministerio de Gobierno. Dirección General de Estadística, Síntesis estadística: año 1927, Paraná, Imprenta Oficial, S/N. 1928. IV Censo General de la Nación: Censo Industrial de 1947, Tomo III....Op. cit., p.LXIX.

${ }^{21}$ Los estadísticas censales entre 1869 hasta 1927 mostraban los siguientes porcentajes comparados: En 1869 la población urbana era aproximadamente el 40\%, en 1895 era cercana al 33,5\% y, según cálculos provinciales, en 1927, la población urbana correspondía al 38,3\% del total de los habitantes de la provincia. Ver: Primer Censo de la República Argentina...Op. cit., p. 171. República Argentina. Segundo Censo Nacional: 1895: población, Buenos Aires, Imprenta de la Penitenciaría Nacional, 1898, Vol. 2, CL
} 
con los años, pero que en algunos departamentos se destaca su grado de urbanidad, como son los casos de Concordia, Gualeguay y Paraná con el 70,7\%, 61,2\% y el 67,1\% de los habitantes en ciudades, respectivamente. Tres de éstas, Concordia, La Paz -sobre ésta última nos referiremos más adelante- y Paraná, crecieron más del cien por cien en el periodo intercensal, lo que las ubica varios puntos por encima del crecimiento promedio de las ciudades del periodo. Con respecto a los departamentos con la mayor población rural, se destacan algunas, como es el caso de Villaguay, Tala y La Paz.

\begin{tabular}{|c|c|c|c|c|c|c|c|c|c|c|}
\hline \multicolumn{11}{|c|}{ Cuadro $N^{\circ}$ 1. Evolución demográfica y urbana/rural, 1914-1947 } \\
\hline \multirow[t]{3}{*}{ Departamento } & \multicolumn{5}{|c|}{1914} & \multicolumn{5}{|c|}{1947} \\
\hline & \multicolumn{2}{|c|}{ Urbano } & \multicolumn{2}{|c|}{ Rural } & \multirow{2}{*}{$\begin{array}{c}\text { Total } \\
\text { Población }\end{array}$} & \multicolumn{2}{|c|}{ Urbano } & \multicolumn{2}{|c|}{ Rural } & Total \\
\hline & Población & $\%$ & Población & $\%$ & & Población & $\%$ & Población & $\%$ & Población \\
\hline Colón & 10.744 & $43,50 \%$ & 13.921 & $56,50 \%$ & 24.665 & 22.062 & $53,50 \%$ & 19.123 & $46,50 \%$ & 41.185 \\
\hline Concordia & 22.577 & $54,80 \%$ & 18.557 & $45,20 \%$ & 41.134 & 61.371 & $70,70 \%$ & 25.395 & $29,30 \%$ & 86.766 \\
\hline Diamante & 6.662 & $33,90 \%$ & 12.965 & $66,10 \%$ & 19.627 & 16.571 & $47,80 \%$ & 18.076 & $52,20 \%$ & 34.647 \\
\hline Federación & 4.347 & $26,70 \%$ & 11.892 & $73,30 \%$ & 16.239 & 17.076 & 51,9 & 15.788 & $49,10 \%$ & 32.864 \\
\hline Feliciano & 1.974 & $21,80 \%$ & 7.074 & 78,2 & 9.048 & 7.643 & $44,20 \%$ & 9.611 & $55,30 \%$ & 17.254 \\
\hline Gualeguay & 12.646 & $44 \%$ & 16.030 & $56 \%$ & 28.676 & 26.122 & $61.2 \%$ & 16.531 & $38,80 \%$ & 42.653 \\
\hline Gualeguaychú & 22.267 & $47,80 \%$ & 24.238 & $52,20 \%$ & 46.505 & 44.193 & $52,90 \%$ & 39.307 & $47,10 \%$ & 83.500 \\
\hline La Paz & 5.504 & $20,80 \%$ & 20.833 & $79,20 \%$ & 26.337 & 25.598 & $43,60 \%$ & 33.072 & $56,40 \%$ & 58.670 \\
\hline Nogoyá & 3.637 & $13,30 \%$ & 23.523 & $86,70 \%$ & 27.160 & 15.826 & $33,80 \%$ & 30.973 & $66,20 \%$ & 46.799 \\
\hline Paraná & 34.346 & $47,80 \%$ & 36.332 & $52,20 \%$ & 71.848 & 99.451 & $67,10 \%$ & 48.655 & $32,90 \%$ & 148.106 \\
\hline Tala & 4.183 & $23,40 \%$ & 13.654 & $76,60 \%$ & 17.837 & 12.768 & $41,40 \%$ & 18.014 & $58,60 \%$ & 30.782 \\
\hline Uruguay & 15.748 & $38,70 \%$ & 24.878 & $61,30 \%$ & 40.626 & 37.315 & $52 \%$ & 34.380 & $48 \%$ & 71.695 \\
\hline Victoria & 12.618 & $51,30 \%$ & 11.961 & $48,70 \%$ & 24.579 & 17.711 & $50,90 \%$ & 17.061 & $49,10 \%$ & 34.772 \\
\hline Villaguay & 7.066 & $22,70 \%$ & 24.026 & $77,30 \%$ & 31.092 & 17.607 & $30,50 \%$ & 40.062 & $69,50 \%$ & 57.669 \\
\hline $\begin{array}{l}\text { Total } \\
\text { provincial }\end{array}$ & 164.319 & $38,60 \%$ & 261.054 & $61,40 \%$ & 425.373 & 421.314 & $53,50 \%$ & 366.048 & $46,50 \%$ & 787.362 \\
\hline \% Medio & & $35 \%$ & & $65 \%$ & & & $50,10 \%$ & & $49,90 \%$ & \\
\hline
\end{tabular}

Fuentes: República Argentina, Tercer Censo Nacional, Tomo II, Población, Buenos Aires, Talleres Gráficos L. J. Rosso y Cía, 1916, pp. 238-249. Ministerio de Asuntos Técnicos, IV Censo General de la Nación, Censo Poblacional, Tomo I, Dirección del Servicio Estadístico, Buenos Aires, 1949, 232.

Si se observa con más atención, se verá que Diamante, Nogoyá, Tala y Victoria -todos departamentos de la región sur-oeste de la provincia- son los que menos crecimiento poblacional han tenido. Deberíamos agregar a Gualeguay, para completar aquella región, lindante con el río Paraná y las provincias de Santa Fe y Buenos Aires. ${ }^{22}$ Surge así hipótesis ¿No serán los departamentos que mantienen la mayor población rural los que más población perdieron, en los cuales sus migrantes no sólo dejaron el campo sino el departamento ya que el ambiente urbano inmediato no les pudo dar ocupación?

y 186. Entre Ríos. Ministerio de Gobierno. Dirección General de Estadística, Síntesis estadística: año 1927 ...Op. cit.

${ }^{22} \mathrm{Y}$ dicho sea de paso, departamentos cerealeros por excelencia, por lo tanto, dónde más debe haber penetrado la mecanización de las tareas rurales favoreciendo la desocupación, y de los cuales, el único que guardaba algún grado de industrialización urbana era Gualeguay. Lo que puede explicar por qué es el único que tiene mayoría de población urbana. 


\section{ARTÍ́CULOS}

Leyes. Caravanas de hombres marchaban: el éxodo obrero en Entre Ríos. 1925-1945.

Esta posibilidad surge de la comparación con los departamentos en los cuales la población urbana creció y parecería que lo hizo en detrimento del campo, aunque, está claro que las ciudades no alcanzaron a contener esa mano de obra sobrante. Algunos casos particulares, como son Gualeguay o La Paz tienen por común la existencia de explotaciones industriales vinculadas específicamente a la industria de la carne, lo que brindó alguna forma de contención estacional de la mano de obra. De todos modos, la respuesta definitiva espera a quien disponga de las fuentes y el interés en responderla. Por nuestra parte aportamos ésta hipótesis basada en los datos disponibles, aunque reconociendo insuficientes.

\section{El proceso en marcha}

El movimiento demográfico no pasó inadvertido para los contemporáneos. Un diario de la ciudad de Paraná retrató con profundidad lo que ocurría en aquel momento en referencia a las migraciones y al consecuente abandono de la provincia. Decía en 1938:

"La terrible depresión económica que se deja sentir desde 1930, y que persiste, aunque con menor intensidad, provocó, entre sus diversas derivaciones, un movimiento migratorio acentuado, aumento en forma extraordinaria la desocupación y los linyeras se vieron cruzar en todas direcciones. Las gentes, en busca de mejoramiento para su situación o en procura de trabajo, evolucionaban de un lado a otro. La necesidad impuso andanzas y adioses y se entreveraron los oficios (...) hubo activas evoluciones internas y corrientes que se proyectaron fuera de los límites provinciales. Trabajadores, y hasta familias enteras, abandonaban su pago con el anhelo de ver mejorada su suerte. Muchos campesinos buscaron refugio en las ciudades, mientras de los suburbios de las ciudades caravanas de hombres marchaban al campo..." (El Tiempo, Paraná, 12/03/1938)

Este recorte guarda en buena medida una impresión realista del sacudón demográfico que estamos historiando en estas páginas. La fecha citada marca la insoluble relación entre la crisis, la desocupación y la migración. También habla de las direcciones tomadas y las clases afectadas. Como se verá a continuación, el éxodo afectó a dos grupos sociales de modo particular: por un lado, amplias fracciones de la clase obrera, en especial, al proletariado rural, con un fuerte peso de la infantería ligera del capital, ${ }^{23} \mathrm{y}$ por otro, a las fracciones más empobrecidas de la pequeña burguesía rural y al proletariado con tierra, que habitó las colonias agrícolas y pequeñas propiedades rurales, mal llamados "campesinos" por el medio citado.

${ }^{23}$ Es la capa de obreros que se caracteriza por el trabajo estacional, la permanente movilidad geográfica en búsqueda de trabajo, el pago mínimo y las peores condiciones de trabajo. Normalmente, son obreros abocados a las tareas de construcción de grandes obras, los recolectores de frutos y cosecheros, los obreros encargados de las faenas en los frigoríficos, la esquila, etc. utilizando los ejemplos típicos en el medio que está en estudio. Ver: Marx, 2001: T. I, 563 
Las formas en las que una clase y la otra concretaron el éxodo muestran diferencias. Mientras los obreros parecen migrar en solitario, los trabajadores con tierra y los chacareros lo hicieron con toda su familia. Se refería a los obreros el órgano de la Federación Libertaria Argentina: "DIAMANTE. Existe gran desocupación por causa del fracaso de dos cosechas en la Provincia de Entre Ríos. La mayor parte de los compañeros han debido emigrar a la zona maicera para poder encontrar trabajo"24. Mientras tanto, relatos como el siguiente se suceden en buena parte de los periódicos locales provinciales:

"Cuadro de miseria. Días pasados tuvimos la dolorosa oportunidad de observar la presencia de una familia compuesta por los padres y cuatro hijos, que se trasladaban a pié en dirección a esta ciudad, de la que se encontraban a pocos kilómetros (...) El aspecto de miseria de los infortunados caminantes nos conmovió hondamente. Sus rostros denotaban hambre y sus cuerpos, apenas cubiertos por unas pocas y rotosas ropas, ponían de manifiesto la enorme tragedia que pesaba sobre sus destinos. Para completar el cuadro desgarrador de esa familia, la madre llevada en brazos un niño de meses quien amamantaba mientras seguía su camino.

Cuadros como éste abundan en nuestra provincia y en el país en general (...) El pueblo que sufre demasiado cruel y seguramente sin culpa ninguna, tiene derecho a que se le atienda. Si se le desconoce ese derecho, puede muy bien llegar el día que se canse y, entonces, las consecuencias de su reacción podrían ser muy perjudiciales." (La Juventud, C. del Uruguay, 23/01/1941) $)^{25}$

En un caso y en otro, la migración no parece haber sido un proceso sin complicaciones, aunque hay que destacar, como decíamos anteriormente, que para una fracción de la clase obrera, la migración ya existía en su forma de vida. La búsqueda de trabajo, movilizarse, estaba entre la manera en que se realizaba la venta de fuerza de trabajo para miles. Esa situación habrá hecho menos traumático el desplazamiento que para aquellos otros que el apartamiento significó la pérdida de la chacra -su medio de vida- y consiguientemente, una movilidad social descendente, es decir, su proletarización. Veamos estos movimientos más de cerca.

\footnotetext{
${ }^{24}$ Acción Libertaria, Buenos Aires, abril de 1936.Mayúscula en el original.

${ }^{25}$ Las publicaciones periodísticas de la provincia asociaban al éxodo, el suicidio, el alcoholismo, y otros males. Ver:La Juventud, 08/06/1943, La Juventud, 06/04/1943, La Juventud, 13/04/1943.
} 


\section{ARTí́culos}

Leyes. Caravanas de hombres marchaban: el éxodo obrero en Entre Ríos. 1925-1945.

\subsection{Del campo a la ciudad: Trabajadores con tierra y pequeña burguesía rural}

La provincia de Entre Ríos poseía en las colonias agrarias el corazón de su agricultura. La llegada de contingentes de migrantes transatlánticos permitió el desarrollo de esta actividad. El promedio de las propiedades era menor a 50 hectáreas, ${ }^{26}$ por lo tanto, se trató de parcelas pequeñas que no permitieron un proceso de acumulación de capitales e inversiones altas, ${ }^{27}$ sino, una economía que rozaba la subsistencia, y derivo en relaciones con una burguesía rural que alquilaba las máquinas trilladoras, centralizaba el almacenaje de los granos, la venta de insumos, cuando no la venta de las parcelas donde habitaba el chacarero y su familia, como lo informó a su tiempo, el ingeniero Eduardo Raña en su informe sobre la situación rural de la provincia de Entre Ríos en 1903(Raña,1904: 153).

Durante la década del 20, los buenos precios de los cereales y las transformaciones tecnológicas facilitaron el acceso a las cosechadoras ("corta-trilla"), a los tractores y a otros nuevos implementos como se explicó más arriba. Por este motivo, buena parte de las relaciones sociales que se habían desarrollado con el estadio tecnológico anterior se transformaron. El chacarero que pudo acceder a las inversiones, que logró arrendar campos y ampliar la superficie para sembrar, prosperó. Pero aquellos que su economía era más sensible a los cambios, que complementaban sus ingresos con la venta de su propia fuerza de trabajo o vivían en un estado de endeudamiento tal que no les permitía acumular capital, cayeron bajo el peso de las deudas que atacaron sus ganancias, finalmente, la competencia capitalista realizó la tarea de limpieza de los capitales menos eficientes. Se siguieron las quiebras, las hipotecas y con ellas la pérdida de los campos, las migraciones y la proletarización de miles $^{28}$.

Más allá de las perspectivas de vida en las ciudades, lo que operó fue la falta de prosperidad en las tareas que aquellos colonos buscaron desarrollar para mantenerse o ascender a las filas de la burguesía rural. Por ejemplo, en 1932, se daba cuenta de que algunos colonos de Federación estaban por migrar rumbo a Brasil, donde se les prometía un mejor futuro, abandonando por ello sus campos hipotecados ${ }^{29}$. Años más tarde, el proceso migratorio se mantenía visible:

"El fracaso de la actual cosecha ha ahondado en forma muy sensible el mal estado reinante entre la población rural, que viene manifestándose desde hace varios años como consecuencia de

\footnotetext{
${ }^{26}$ Hacia 1914, de 22.801 propiedades existentes en la provincia, 9.372 correspondían a propiedades menores a 50 hectáreas, seguidas por 4.276 hectáreas de entre 50 y 100 hectáreas y 7.182 propiedades que tenían una superficie de entre 100 a 500 hectáreas. Ver República Argentina. Tercer Censo Nacional, Tomo V, Explotaciones Agropecuarias, Buenos Aires, Talleres Gráficos L. J. Rosso y Cía, 1919, p.3.

${ }^{27} \mathrm{Al}$ respecto de la acumulación -en términos competitivos y comparados- menores de las colonias entrerrianas frente a sus pares de otras provincias ver:Djenderedjian, J., Bearzotti, S. \&Martirén, J. L. 2010: 665, T.II.

${ }^{28}$ Esta explicación la hemos desarrollado con mayor amplitud en mi tesis de Licenciatura en Historia, "Trabajo, sudor y Sangre: Génesis y transformaciones de la clase obrera vinculada al desarrollo agrario y manufacturero en Entre Ríos, 1858-1946", defendida en Febrero de 2013, en la Facultad de Humanidades, Artes y Ciencias sociales de la Universidad Autónoma de Entre Ríos.

${ }^{29}$ El Entre Ríos, Colón, 06/09/1932.
} 
la permanente desvalorización de los productos agrícolas y de la serie de inconvenientes de todo orden (...)La emigración a que nos referimos no solo no ofrecerá las soluciones anheladas sino que creará nuevas dificultades a la población urbana, no solamente por abultar demasiado el eterno problema de la desocupación obrera, sino porque las ciudades no pueden ofrecer las comodidades necesarias a un núcleo demasiado crecido de gentes que llegan a su seno sin recursos y hasta sin los elementos propicios de uso personal" (La Juventud, C. del Uruguay, 13/01/1945).

La noticia refleja el estado de la época, donde los factores coyunturales (la pérdida de las cosechas) se entremezclan con otros más estructurales, como son las deudas acarreadas por malos años, la desocupación persistente y la falta de capacidad de las ciudades de ordenar a los recién llegados en tareas productivas, es decir, su absorción dentro del mercado. En el caso entrerriano, para muchos el proceso migratorio continuó fuera de la provincia, se trataría pues, de un movimiento del campo al pueblo, del pueblo a la ciudad. La ciudad se encontraba en otra provincia.

\subsection{Cruzando el río: Éxodo obrero}

Si entre la pequeña burguesía rural y los trabajadores con tierra operó un proceso de proletarización, sobre la clase obrera, otra era la consecuencia. Se estaba produciendo una temprana conformación de sobrepoblación obrera. Miles de obreros serán innecesarios para el proceso de valorización gracias a las nuevas tecnologías y le sobran al capitalismo que los expulsa (Kabat, 2009: 109-128).

Las migraciones obreras que nos ocupan, comienzan en el preludio de la gran crisis económica de 1929. Tienen además un componente estructural novedoso, donde la desocupación permanente es la que empujó a los obreros fuera de la provincia. Hasta ese momento, como se dijo más atrás, la migración de los obreros entrerrianos se trataba de un proceso estacional. Sin embargo, las cosas habían cambiado:

"En épocas que escasea el trabajo en la provincia, el obrero entrerriano se traslada de una parte a otra o abandonando el territorio provincial hacia las provincias de Buenos Aires y Santa Fe y así mismo hacia los frigoríficos de las márgenes del Riachuelo y de La Plata, donde actualmente hay gran cantidad de obreros entrerrianos. Este movimiento se registra todos los años. Según la región, es el rumbo que toma el movimiento migratorio entrerriano. Así tenemos que los que abandonan Victoria se dirigen especialmente a Rosario, mientras en otras partes se registran evoluciones dentro del mismo territorio. Algunas ciudades como Gualeguaychú y Concepción del Uruguay que cuentan con fuentes de trabajo de que carecen 
otras ejercen cierta atracción para los trabajadores deseosos de emplear sus brazos, y asimismo sucede con Concordia, Colón y la localidad de Santa Elena [en La Paz] merced a sus establecimientos frigoríficos. Otros buscan el rumbo de la capital federal, que no siempre responde al grado de atracción que ejerce.”(El Tiempo, Paraná, 12/03/1938)

La nota continúa hablando de lo que denomina "ruta nogayaense", en referencia al desplazamiento de habitantes de Nogoyá y su campaña -en el centro sur de Entre Ríos- rumbo a la ciudad de Paraná: "Nogoyá se está quedando sin gente. A cada paso me topo con un ciudadano o ciudadana de mi pueblo. Nos estamos viniendo todos..." afirmaba el periodista. Uno de los migrantes ha dejado un rico relato de aquel momento. Nos referimos al relato de José Peter, dirigente comunista del sindicato de la carne. Originario de Estación Lazo, a pocos kilómetros de Gualeguay, donde su familia poseía una pequeña chacra. En pleno proceso de proletarización, Peter decidió marcharse poco antes de la mitad de la década de 1920:

“...tomé un día el tren en la estación Lazo para trasladarme a la provincia de Buenos Aires a trabajar en la deschalada de maíz. En la cumbrera del galpón de la última chacra en que trabajé como peón, colgué mi apero que tantos años me había acompañado (...) Allá quedaron esos campos, esas costas de ríos y bosques, por donde había paseado muchas de mis esperanzas (...) Allá dejaba mi querido Entre Ríos. No resultaba fácil alejarme de todo eso que me era tan querido y entrañable. Pero no había más remedio, el hambre y la pobreza son crueles y no admiten términos medios: o se muere de hambre o se lucha con él buscando otros horizontes. Lo cierto es que yo también, como todos los trabajadores que venimos del interior, anhelaba vivir bajo un techo más o menos permanente, trabajar en un lugar fijo. Estaba cansado de esa vida nómada que había hecho durante los últimos años; harto de dormir bajo los talas, sobre la paja de las trilladoras o sobre sucios cueros en las estancias. Había que decidirme, y yo, como tantos lo hicieron antes y después, enfilé hacia nuevos rumbos. Mi patria se me abría amplia y grandota, con mi modesta carga de pobreza y esperanza..." (Peter, 1968: 14-15)

Luego de un viaje en barco, en el que se describe el cuadro de miseria de sus pasajeros, todos con un boleto de segunda clase, da cuenta de la profunda impresión que le causó ver a los trabajadores entrar a los grandes frigoríficos de Zárate. Se dirigió a una chacra donde trabajó como deschalador de maíz. Luego de plantearle al propietario de la chacra -posteriormente su cuñado- las intenciones de ingresar a trabajar en el 
frigorífico, al que ingreso con una recomendación. Peter cuenta que le envió unos pesos ahorrados a su madre y se desplazó a Zárate:

"En Zárate nos relacionamos con algunos obreros de mi provincia, quienes nos facilitaron albergue y ayuda hasta que nos ubicáramos y encontráramos trabajo. Nos hicieron dar crédito en el bolichito de la villa Angus..." (Peter, 1968: 19)

Aquí la solidaridad de otros co-provincianos sirvió como carta de entrada y el desarrollo de una vida que continuó fuera de Entre Ríos. Existen otros casos particulares, de conocidos obreros entrerrianos que debieron irse. Ángel Borda, dirigente anarquista de la Federación Obrera Comarcal Entrerriana y uno de los fundadores de la Federación Libertaria Argentina, migró a Buenos Aires a principio de la década del `40, después de años de luchas sindicales y el fracaso de la Comarcal(Borda, 1987: 212).O Antonio Aguilar, migrante de principio de los treinta a Buenos Aires, originario de Gualeguaychú, destacado miembro de esa Seccional de la Federación Obrera Marítima (FOM) y luego secretario administrativo de aquella durante el periodo 1945-1947, previo a la unificación en el Sindicato de Obrero Marítimo Unidos (SOMU). (Di Tella, 2003: 252) Como resulta lógico, fueronmiles los emigrados anónimos de los cuales no sabemos más que lo dicho por los medios periodísticos o las estadísticas, en el mejor de los casos.

\section{Política de clase}

Los discursos emitidos por los diferentes medios periodísticos de la clase dominante muestran cómo se conformó una idea común referente a los desocupados. Con matices, entre los posibles tratos, facilitar su emigración, era una de ellas. La reconstrucción histórica muestra que en el momento que la desocupación comenzó hacerse notar, los medios periodísticos burgueses bregaron por la migración entre las posibles medidas para combatir la desocupación. En un temprano 1925, el diario radical Del Pueblo, de Colón informó:

"En el ministerio de Agricultura se ha recibido hoy los primeros productos de la actual cosecha algodonera. Al mismo tiempo, diversas comunicaciones enviadas de las regiones productoras del Chaco ponen manifiesto el ancho campo que se ofrece para las personas que quisieran dedicar sus esfuerzos a la recolección del producto, dado que se prevé la falta de brazos para tal objeto. Es esta una oportunidad para los que necesitan trabajo..." (Del Pueblo, Colón, 03/03/1925.)

Noticias de este tenor aparecieron al año siguiente cuando la fábrica Liebig procesadora de extracto de carne- cerró sus puertas ${ }^{30}$. Las noticias guardan el carácter estacional de la desocupación y los destinos propuestos son, como la noticia anterior, provincias como el Chaco o Misiones. Estamos, parecería, aún frente a la migración

${ }^{30}$ El Entre Ríos, Colón, 13/04/1926. 
de carácter estacional, sin embargo, la gran mayoría de las prensas consultadas han observado que el proceso de emigración obrera se masificó en los primeros años de la década del 30. A pesar de ello, la política general de facilitar la emigración se mantuvo. Un periódico de Paraná daba cuenta en 1933 de las peripecias que debían soportar los migrantes que se proponían desplazar a Santa Fe. Luego que habían pedido ayuda a las autoridades provinciales y a la Prefectura para solicitar su traslado a la costa opuesta, habían sido desplazados por una empresa de tráfico fluvial privada: "Hace más simpático este gesto de solidaridad humana de los señores Lahargue y colobig el haber obsequiado a los mismos con comestibles diversos para que se alimenten durante el viaje" decía el periódico. $^{31}$

Los medios de prensa expresan las opiniones de los círculos a los que pertenecen. En este sentido, se destaca que tanto radicales como conservadores, expresaron una política en términos generales de favorecer discursivamente el desplazamiento de los obreros desocupados sin demasiado resquemor. Pero también, la comprensión de que la migración era solo un paliativo. Por ejemplo, el periódico católico La Acción de Paraná, luego de presentar el escenario de falta de trabajo e informar la situación de los obreros que migraban a buscar trabajo a Santa Fe se preguntaba que harían los trabajadores una vez que terminaran de trabajar allí:

\begin{abstract}
"Es el caso entonces de crear trabajo, de proporcionar ocupación a estos elementos y el gobierno debe emprender obras de interés público, que vengan en ayuda de esta gente obrera, proporcionándoles trabajo y en consecuencia, el pan de cada día. Entre los buenos propósitos exteriorizados por el gobierno, se contaba, si la memoria no nos es infiel, un plan orientado en el sentido de combatir la desocupación: la oportunidad de hacerlo efectivo no ha de escatimarse, sin duda" (La Acción, Paraná, 11/03/1936)
\end{abstract}

Algo análogo informó en 1945, del otro lado de la provincia, en la localidad de Colón, el periódico conservador El Entre Ríos. Dando por hecho que la migración de los elementos obreros de la región, demandaba el pedido de industrialización para cuando los trabajadores retornaran ${ }^{32}$.

Veinte años distaban unas noticias de las otras. La clase dominante aún se preguntaba qué hacer cuando los emigrados regresaran. Sin embargo no volvieron. El Estado provincial era alcanzado por un llamado de diferentes frentes a la intervención estatal cuando, hipotéticamente la válvula de escape se cerrara y los migrantes volvieran, mientras tanto, la emigración era preferible. El consenso alcanzado en la experiencia de una economía que no salía de la crisis, había allanado o impuesto el camino que desde la intervención de los militares en 1943 hasta el programa del gobernador peronista

\footnotetext{
${ }^{31}$ El Tiempo, Paraná, 09/03/1933.

${ }^{32}$ El Entre Ríos, Colón, 03/04/1945.
} 
elegido en 1946, buscaran materializar la industrialización de la provincia. Frente a la Asamblea Legislativa, Héctor Maya, juró a la gobernación y señaló:

"En nuestras ciudades, especialmente en sus suburbios, vive una población pauperizada que no tiene donde trabajar, en su gran mayoría, la mitad de los días hábiles del año y que, muchas veces, debe buscar transitoriamente su sustento en otras provincias, viéndose obligada abandonar material y moralmente sus familias con los graves problemas sociales consiguientes. Obedece esto a la escasez de trabajo. Crearlo ha de ser una de nuestras preocupaciones esenciales." (Maya, 1946: 8)

Para 1960 se calculaba que la cantidad de entrerrianos fuera de la provincia era de unos 300 mil (Felquer y Moreira Bahler, 1962: 129) ${ }^{33}$.

\section{El Estado presente... para la expulsión}

Uno de los aspectos que no se puede omitir es la tarea del Estado frente a los migrantes. En este sentido, indicar la convivencia entre el Estado provincial y el nacional en la ejecución de planes comunes para permitir la emigración. El Estado se adjudicó la función práctica de emigrar a los obreros sobrantes como una medida de contención social. Utilizó para ello a la Junta Nacional para Combatir la Desocupación.

La Junta Nacional para Combatir la Desocupación (JNCD) fue una repartición del Estado nacional que nació al calor de la crisis económica y en sintonía con otras reparticiones que buscaban la intervención estatal en espacios de la vida social vedados anteriormente. Su creación se remonta a 1932 y estaba compuesto por miembros del Congreso ( 3 senadores y 5 diputados). ${ }^{34}$ Entre sus planes se destacaban la asistencia a los desocupados en estado de indigencia, calificar y mejorar la calificación de los obreros desocupados, proponer al ejecutivo medidas para combatir la desocupación, concentrar en campos especiales a los obreros sin calificación y lógicamente, facilitar el traslado de obreros a los lugares donde exista trabajo, que de hecho era el segundo punto de las propuestas (Girbal-Blacha, 2003: 29).

La Memoria de la JNCD de 1936 da cuenta de la tarea de traslado indicando que 1.032 braceros, compuestos por entrerrianos, santafecinos y bonaerenses habían sido trasladados al Chaco. Entre las gestiones desarrolladas por la Junta se destaca la centralización de la demanda de trabajo $0^{35}$ y la facilidad para el traslado con tarifas

${ }^{33}$ La población provincial era entre 800 mil a un millón de habitantes, por lo que estamos hablando de entre el 25 al 30\% de sus nacidos fuera de la provincia.

${ }^{34}$ Para un resumen histórico de la Junta Nacional para Combatir la Desocupación y los debates consultar: Girbal-Blacha, 2003.

${ }^{35}$ La centralización de las tareas de traslado y colocación de los asalariados es una muestra de los cambios que operaban en el seno de la clase dominante, que buscaba superar las situaciones anteriores dónde esas medidas eran realizadas por empresarios privados, que abusaban de los trabajadores. Ver: Bialet Massé, J., 1985: Cap. XX, T. II. 
reducidas - con descuentos de hasta un $89,5 \%$ del costo del pasaje-. (Junta Nacional para Combatir la Desocupación, 1936: 18-23. Y Apéndice N²). En 1937 la JNCD envió a los gobernadores una encuesta para dar cuenta del estado de situación. El correspondiente a la provincia de Entre Ríos fue respondido por el presidente del Departamento de Trabajo provincial, Acevedo Recalde, qué informó que la desocupación ascendía a unos 20 mil trabajadores, particularmente trabajadores rurales que se dirigían a Buenos Aires y Santa Fe en procura de trabajo, además agregaba que el gobierno provincial comenzaba tareas de "colonización oficial" para contener a la mano de obra y que el desarrollo industrial era una necesidad para contener a la población ${ }^{36}$.

El año 1938 encontró al Estado en plena tarea de movilizar a la mano de obra sobrante entrerriana. Con el elocuente título de "Una buena iniciativa" una de las prensas comerciales de la época decía:

"Una iniciativa sin duda oportuna, acaba de tomar el Departamento del Trabajo de la provincia, que ha de favorecer a no pocos obreros. Conocido es el éxodo de braceros, que en ésta época del año, se inicia hacia las provincias de Buenos Aires y Santa Fe, con el propósito de la cosecha de maíz (...) Hasta ahora, ese éxodo se ha ido haciendo, sin intervención de las autoridades, mediante la sola iniciativa de los interesados que iniciaban todos los años su larga peregrinación por los caminos hasta llegar a los puntos, que creían más oportunos para conseguir el propósito buscado (...) se busca organizar, en forma racional ese éxodo de braceros, indicándoles los lugares donde puedan encontrar ocupación y proveyéndolos al mismo tiempo de los pasajes necesarios para llegar al sitio elegido.

Con el fin de llevar a feliz término este propósito, se ha requerido la cooperación de la Junta Nacional para combatir la Desocupación y de los departamentos del trabajo de las provincias de Buenos Aires y Santa Fe." (El Entre Ríos, Colón, 05/03/1938)

Esas actividades eran nada menos que conseguir el pan de cada día. El cambio de gobierno producto de la Revolución de Junio no cambió el destino del proletariado sobrante. En 1944, se publicaba:

"La Secretaría de Trabajo y Previsión dio el siguiente comunicado de prensa: 'La dirección de agronomías regionales del ministerio de Agricultura de la Nación ha comunicado a la delegación Regional de Trabajo y Previsión, que en la zona algodonera del territorio nacional del Chaco existe considerable demanda de obrero para las tareas de recolección del textil -y continuaba- Los F.F.C.C. del Estado y de Santa Fé acuerdan

${ }^{36}$ Junta Nacional para Combatir la Desocupación, 1937: 98. 
apreciables rebajas en los pasajes para aquel destino. Advierte la delegación regional de la Secretaría de Trabajo y Previsión que los braceros de esta provincia que deseen trasladarse a Chaco, lo deberán hacer a su exclusiva costa, en razón de que carece de medios para solventar esos gastos'" (La Juventud, Concepción del Uruguay, 02/05/1944.)

El Estado continuaba como veedor de la situación de los desocupados, pero la situación no ameritaba hacerse cargo de los gastos de traslado. Sin embargo, se continuó alentando la emigración de los desocupados. Los resultados prácticos de esta política estatal son mínimos si consideramos los miles que se fueron de la provincia, pero no deja de ser destacable el cambio en la concepción sobre la intervención y su relación con la clase obrera.

\section{Conclusión}

El capitalismo, lejos de lo que se pudiera creer, es un sistema en permanente conmoción. Aunque vale agregar que todo el movimiento de transformación lo hace dentro de determinadas lógicas. El máximo axioma de este sistema es la búsqueda permanente de ganancias. Para ello hace falta estar dentro de la media productiva en la rama en que se compite. Esto se logra alcanzando una explotación eficiente de la mano de obra y la inversión en maquinarias. De otro modo, la pérdida de competitividad no perdona, y el capitalista individualmente quiebra.Por otra parte, las inversiones en capital constante (máquinas) afectarán la ocupación de la mano de obra y trastoca las fuerzas productivas. Así que el desplazamiento de la fuerza de trabajo en su sujeto portador, el obrero, ha sido una constante desde los tiempos que el capitalismo comenzó a dar sus primeros pasos y mientras este exista, seguirá siendo así. Miles de migrantes rumbo a los llamados "países ricos" y regiones más desarrolladas, así lo atestiguan hoy día en un incesante movimiento demográfico que desplaza a los expropiados rumbos a los lugares donde el capital esté dispuesto a explotarlos, si es que esas condiciones existen.

Por nuestra parte, nos ocupamos de un tipo de migración particular vivida durante la década de 1920 hasta 1945, en la provincia argentina de Entre Ríos. El acercamiento territorial y provincial responde a varios intereses. En primer lugar, dar cuenta del debate suscitado sobre el surgimiento del peronismo y el lugar que les cabía a los migrantes internos, ubicando a los migrantes en el centro de los debates. De las posiciones existentes sobre el rol jugado por los migrantes, nos inclinábamos por las denominadas hipótesis "heterodoxas" o revisionistas, en detrimento de los planteos hechos por Germani, quien había cargado a los obreros migrantes con un estereotipo donde los obreros migrantes serían de la periferia del agro-pampeano, además de ignorantes en las prácticas políticas y ajenos a la asociación gremial, y finalmente, victimas incrédulas de los manejos manipuladores de Perón. 
La provincia de Entre Ríos reviste un interés particular en su estudio. Expulsora crónica de población, el capitalismo acotado al espacio provincial encontró un techo en el consumo de fuerza de trabajo al cruzar el umbral de la moderna manufactura hacía la gran industria en sus actividades más dinámicas, durante la mitad de la década del '20 y las siguientes. El reemplazo de mano de obra por máquinas, dejó a miles de obreros sin trabajo y a una porción no menor de chacareros y semi-proletarios con tierra en la completa quiebra. De estos dos grupos se nutren los migrantes. La proletarización de los chacareros pobres y proletarios con tierra significó un aumento en la oferta de fuerza de trabajo, por lo tanto, un perjuicio para los obreros que ya, por el contexto de disminución de la ocupación, encontraban dificultades para vender su propia fuerza de trabajo.

Si bien el proletariado de la provincia de Entre Ríos participó en los trabajos de cosecha de las dos provincias vecinas y más ricas -Santa Fe y Buenos Aires-, las modificaciones en el aparato productivo local hicieron que estos obreros tengan que utilizar la migración, no como un hecho complementario a su forma de conseguir medios de vida, sino como un hecho persistente. Flanqueados por la miseria y la desocupación, irse resultó una solución individual viable. Cabe preguntarse: ¿Había otra alternativa?

Con respecto a las migraciones, también es necesario agregar que estas no guardaron una sola dirección geográfica. Si bien se destaca la provincia de Buenos Aires y en particular la ciudad homónima, otras provincias como Santa Fe y el Chaco, resultaron receptoras de entrerrianos durante un tiempo. Tampoco se debería descuidar el papel ocupado por el Estado a la hora de la emigración, facilitando los medios para que los trabajadores especialmente, se vayan de la provincia. En tanto, a la pequeña burguesía rural y al proletariado con tierra se intentó contener en la tierra y detener el proceso histórico-social con planes de colonización "oficial” (Biasizo, 2015: 87 y ss.).

Una pregunta pendiente para otro trabajo es: ¿Qué pasó con los sindicatos cuando sus bases abandonan su espacio de representación? Adelantamos como hipótesis que es posible que el reformismo creciente de los sindicalistas entrerrianos y su aceitada relación con los políticos radicales tenga que ver con la necesidad de contar con el apoyo de un poder extra a la movilización de sus propias fuerzas -raleadas por la desocupación y la emigración-. Y en la misma línea, se explica parte del problema de porqué el laborismo entrerriano recurrió a un político de FORJA para candidato a gobernador y no a un sindicalista (Aelo, 2015), integrados tácitamente con el radicalismo.

La migración es un proceso por demás complejo, para nada unilineal como se suele simplificar. Con esto destacar que no es un tema agotado ni mucho menos, el desafío metodológico para salvar los errores y carencias del material censal, un estudio que abarque el conocimiento de los espacios territoriales y desde los cuales se pueda afirmar o rechazar tesis serán tareas por desarrollar. Vaya en esa dirección nuestro aporte. 


\section{Referencias bibliográficas}

\section{Fuentes}

Diario Del Pueblo, Colón, 1925 y 1938.

Diario El Tiempo, Paraná, 1933 y 1938.

Diario La Acción, Paraná, 1936.

Periódico Acción Libertaria, Órgano de la Federación Libertaria Argentina, Buenos Aires, abril de 1936.

Periódico El Despertar, Órgano de la Unión Obrera de Concepción del Uruguay, Enero de 1936.

Periódico El Entre Ríos, Colón, 1925-1945.

Periódico La Juventud, C. del Uruguay, 1941-1945.

\section{Estatales}

Bialet Massé, J. 1985. Informe sobre el estado de la clase obrera, Buenos Aires, Hyspamerica Ediciones, T. I.

Entre Ríos. 1928. Ministerio de Gobierno. Dirección General de Estadística, Síntesis estadística: año 1927, Paraná, Imprenta Oficial, S/N.

Entre Ríos. 1930. Ministerio de Gobierno. Dirección General de Estadística, Síntesis Estadística: Año 1929, Paraná, Imprenta Oficial.

Entre Ríos. 1944. Ministerio de Hacienda, Dirección General de Estadística, Síntesis Estadística: Año 1943, Paraná, Imprenta de la Provincia.

Entre Ríos. 1946. Ministerio de Hacienda, Dirección General de Estadística, Síntesis Estadística: Año 1944-1945, Paraná, Imprenta de la Provincia.

Maya, H. 1946.Mensaje del Gobernador de Entre Ríos al prestar juramento ante la Asamblea Legislativa, 22 de mayo de 1946, Paraná, Imprenta de la Provincia.

Ministerio de Agricultura. 1917. Estadística comercial e industrial de la Provincia de Entre Ríos, Boletín N ${ }^{\circ} 26$.

Ministerio de Agricultura. 1940. Censo nacional agropecuario: 1937, Buenos Aires, Guillermo Kraft Ltda.

Ministerio de Agricultura.1938. Censo General agropecuario de 1937: resultados generales (Cifras Provisionales), Buenos Aires, S/E.

Ministerio de Asuntos Técnicos. 1949. IV Censo General de la Nación, Censo Poblacional, Tomo I, Dirección del Servicio Estadístico, Buenos Aires.

Ministerio de Hacienda. 1938. Comisión Nacional del Censo Industrial, Censo Industrial de 1935, Buenos Aires, DGEN- Casa Jacobo Peuser.

República Argentina. 1872. Primer Censo de la República Argentina, verificado en los días 15, 16 y 17 de 1869, Buenos Aires, Imprenta El Porvenir.

República Argentina. 1898. Segundo Censo Nacional: 1895: población, Buenos Aires, Imprenta de la Penitenciaría Nacional, Vol. 2. 
República Argentina. 1909. Censo Agropecuario Nacional, la ganadería y la agricultura en 1908: La Ganadería, Buenos Aires, Talleres de Publicaciones de la Oficina Meteorológica, Vol. I.

República Argentina. 1916. Tercer Censo Nacional, Tomo I, Antecedentes y comentarios, Buenos Aires, Talleres Gráficos L. J. Rosso y Cía.

República Argentina. 1947. Ministerio de Asuntos técnicos del Estado, Dir. Gen. Del Serv. Est. Nacional, IV Censo General de la Nación: Censo Agropecuario de 1947, Tomos I y II, Buenos Aires, Dirección Nacional del Servicio Estadístico.

República Argentina. 1952. Ministerio de Asuntos técnicos del Estado, Dir. Gen. Del Serv. Est. Nacional, IV Censo General de la Nación: Censo Industrial de 1947, Tomo III, Buenos Aires, Dirección Nacional del Servicio Estadístico.

República Argentina.1919. Tercer Censo Nacional, Tomo V, Explotaciones Agropecuarias, Buenos Aires, Talleres Gráficos L. J. Rosso y Cía.

\section{Bibliografía}

Acha, O. 2008. "Migración interna y formación de parejas en Buenos Aires en los años del primer peronismo: Una perspectiva de historia social sobre una zona popular", en Anuario IEHS, No 23, Tandil.

Aelo, O. 2015. "El origen del peronismo. Una aproximación interprovincial", en Trabajos y comunicaciones, $\mathrm{N}^{0}$ 41, marzo 2015, Universidad Nacional de La Plata, Facultad de Humanidades y Ciencias de la Educación. Departamento de Historia.

Amaral, S. 2015. "Los migrantes recientes y el voto peronista: los nuevos inscriptos en las elecciones del 24 de febrero de 1946" en Pasado Abierto. Revista del CEHis, Mar del Plata, Julio-Diciembre.

Argentine Republic. 1925. The province of Entre Rios, Economical Political and Geographical synthesis, S/L, S/E.

Barcón Olesa, J. 1912.El estado de Entre Ríos. Álbum gráfico y exposición sintética de sus elementos de progreso, Paraná, $\mathrm{S} / \mathrm{E}$.

Barreto, I. 2003. Liebig's: fábrica y pueblo, C. del Uruguay, Artes Gráficas Yuste.

Barsky, O. y Gelman, J. 2005. Historia del agro argentino, Buenos Aires, Mondadori.

Biaziso, R. 2015. Economía de Entre Ríos en el periodo de intervencionismo conservador, 1930-1945, Paraná, Universidad Nacional de Entre Ríos, UNER.

Borda, A. 1987. Perfil de un libertario, Buenos Aires, Editorial Reconstruir.

Cantón, D.; Acosta, L.; Jorrat, J. 2013.Una hipótesis rechazada: el rol de los migrantes internos según Gino Germani en los orígenes del peronismo, Buenos Aires, Buenos Aires, Hernández Editores.

Di Tella, T. 1964.El sistema politico argentino y la clase obrera, Buenos Aires, EUDEBA.

Di Tella, T. 2003.Perón y los sindicatos, Buenos Aires, Ariel. 
Djenderedjian, J.; Bearzotti, S.; Martirén, J. L. 2010. Historia del Capitalismo agrario pampeano: expansión agricola y colonización en la segunda mitad del siglo XIX, Buenos Aires, Teseo/Universidad de Belgrano, T.II.

Felquer, J. y Moreira Bahler, L. 1962. Geografía Física, biológica, humana de Entre Ríos, Paraná, Ed. Nueva Impresora.

Germani, G. 1962. Política y sociedad en una época de transición, Buenos Aires, Paidos.

Germani, G. 1980. "El surgimiento del peronismo: El rol de los obreros y de los migrantes internos" en M. Mora y Araujo \& I. Llorente (Comp.), El voto peronista, Buenos Aires, Ed. Sudamericana, pp.87-163.

Germani, G. 1992. "Peronismo, 1973" en J. Jorrat\& R. Sautu (Comp.): Después de Germani, Buenos Aires, Paidos, pp.79-85.

Giberti, H. 1986. Historia económica de la ganadería argentina, Buenos Aires, Solar.

Girbal Blacha, N. 2003. "La Junta Nacional para Combatir la Desocupación. Tradición y modernización socioeconómica en la Argentina de los años treinta" en Estudios del Trabajo, No25, Enero-Febrero, Buenos Aires, 25-53.

Halperín Donghi, T. 1980. “Algunas observaciones sobre Germani, el surgimiento del peronismo y los migrantes internos" en M. Mora y Araujo \& I. Llorente (Comp.), El voto peronista Buenos Aires, Ed. Sudamericana, pp.219-250.

Henchóz, M. 2013. "La migración interna en el sudeste entrerriano hacia 1940" en revista Tiempo de Gestión, Gualeguaychú No 15, Julio, Facultad de Ciencias de la Gestión, UADER, 29-44.

Hobsbawm, E. 2005. La era del capital, 1848-1875, Buenos Aires, Critica.

James, D. 2013. "Los orígenes del peronismo y la tarea del historiador" en Revista Archivos de historia del movimiento obrero y la izquierda, Buenos Aires, Año II, No3, Septiembre.131-147.

Kabat, M. 2009. "La sobrepoblación relativa. El aspecto menos conocido de la concepción marxista de la clase obrera" en Anuario CEICS 2009, Año 3, Número 3, Buenos Aires. 109-128.

Korzeniewicz, R. 1993. "Las migraciones internas en los orígenes del peronismo: tres observaciones empíricas" en Ciclos, Buenos Aires, Año III, Vol. III, No5, 2do. Semestre.

Leyes, R. 2013. No culpes a la crisis: inversiones de capital, mecanización y desocupación en Entre Ríos, 1928-1946. En las XIV Jornadas Interescuelas/Departamentos de Historia, 2 -5 de octubre de Departamento de Historia de la F. F. y L. /U.N.C., Mendoza.

Marx, C. 2001. El Capital, México D.F., F.C.E., T. I.

Monteagudo, P. I. 1956. Migraciones internas en la Argentina y utopías revolucionarias de Lisandro de la Torre, Buenos Aires, Com. Nac. De Homenaje a Lisandro de la Torre.

Murmis, M. y Portantiero, J. C. 2006. Estudio sobre los orígenes del peronismo, Buenos Aires, Siglo XXI Editores.

Peter, J. 1968. Crónicas proletarias, Buenos Aires, Esfera. 


\section{ARTÍ́CULOS}

Leyes. Caravanas de hombres marchaban: el éxodo obrero en Entre Ríos. 1925-1945.

Quiroga, N. 2016. "Mezclando cosas. Migrantes internos, peronismo y temperamentos regionales" en Avances del Cesor, V. XIII, N 14, Primer semestre, 2016.

Recchini de Lattes, Z. \& Lattes, A. 1969. Migraciones en la Argentina, Buenos Aires, EIDT.

República Oriental del Uruguay. Comisión de Ganadería, Ramos Montero, A. (1910). La esquila con máquina: resultados que ha producido en el país, Montevideo, Talleres Barreiro.

Rodríguez, J. 1988. Vivencias, Concepción del Uruguay, Talleres Yusti.

Sartelli, E. 1993. "Sindicatos obreros-rurales en la región pampeana, 1900-1922” en A., Waldo (comp.): Conflictos obreros rurales pampeanos, 1900-1937, Buenos Aires, CEAL. T. III. 293-328.

Sartelli, E. 1995. "Del asombro al desencanto: La tecnología rural y los vaivenes de la agricultura Pampeana", en: A. Reguera y M. Bjerg (comp.). Sin estereotipos ni mitificaciones. Problemas, métodos y fuentes de la historia agraria, IHES, Tandil, Reedición electrónica.

Sartelli, E. 1997. "Ríos de oro y gigantes de acero. Tecnología y clases sociales en la región pampeana", en Revista Razón y Revolución, $\mathrm{N}^{\circ} 3$, pp. 5-32.

Sartelli, E. (Dir.). 2008. Patrones en la ruta, Buenos Aires, Ediciones R y R.

Villanueva, J. 1972. "El origen de la industrialización argentina", en Desarrollo Económico, Buenos Aires, Vol. 12, No 47, Octubre-noviembre. 451-476. 